\title{
Literature-based latitudinal distribution and possible range shifts of two US east coast dune grass species (Uniola paniculata and Ammophila breviligulata)
}

\author{
Evan B Goldstein ${ }^{\text {Corresp.. }}{ }^{1}$ ， Elsemarie V Mullins ${ }^{1}{ }^{\text {, }}$ Laura J Moore ${ }^{1}{ }^{\text {, }}$, Reuben G Biel ${ }^{1}$, Joseph K Brown ${ }^{2}$, Sally D \\ Hacker $^{3}$, Katya R Jay ${ }^{3}$, Rebecca S Mostow ${ }^{3}$, Peter Ruggiero ${ }^{4}$, Julie C Zinnert ${ }^{2}$ \\ ${ }^{1}$ Department of Geological Sciences, University of North Carolina at Chapel Hill, Chapel Hill, North Carolina, United States \\ 3 Department of Integrative Biology, Oregon State University, Corvallis, Oregon, United States \\ ${ }^{4}$ College of Earth, Ocean, and Atmospheric Sciences, Oregon State University, Corvallis, Oregon, United States
}

Corresponding Author: Evan B Goldstein

Email address: evan.goldstein@unc.edu

Previous work on the US Atlantic coast has generally shown that coastal foredunes are dominated by two dune grass species, Ammophila breviligulata (American beachgrass) and Uniola paniculata (sea oats). From Virginia northward, A. breviligulata dominates, while $U$. paniculata is the dominant grass south of Virginia. Previous work suggests that these grasses influence the shape of coastal foredunes in species-specific ways, and that they respond differently to environmental stressors; thus, it is important to know which species dominates a given dune system. The range boundaries of these two species remains unclear given the lack of comprehensive surveys. In an attempt to determine these boundaries, we conducted a literature survey of 98 studies that either stated the range limits and/or included field-based studies/observations of the two grass species. We then produced an interactive map that summarizes the locations of the surveyed papers and books. The literature review suggests that the current southern range limit for $A$. breviligulata is Cape Fear, NC, and the northern range limit for U. paniculata is Assateague Island, on the Maryland and Virginia border. Our data suggest a northward expansion of $U$. paniculata, possibly associated with warming trends observed near the northern range limit in Painter, VA. In contrast, the data regarding a range shift for $A$. breviligulata remain inconclusive. We also compare our literature-based map with geolocated records from the Global Biodiversity Information Facility and iNaturalist research grade crowd-sourced observations. We intend for our literature-based map to aid coastal researchers who are interested in the dynamics of these two species and the potential for their ranges to shift as a result of climate change. 
1 Literature-based latitudinal distribution and possible range shifts of two US east coast dune grass

2 species (Uniola paniculata and Ammophila breviligulata)

3

4 Evan B. Goldstein ${ }^{*}$, Elsemarie V. Mullins ${ }^{1}$, Laura J. Moore ${ }^{1}$, Reuben G. Biel ${ }^{1+}$, Joseph K.

5 Brown $^{2+}$, Sally D. Hacker ${ }^{3+}, \mathrm{Katya} \mathrm{R.} \mathrm{Jay}^{3+}$, Rebecca S. Mostow ${ }^{3+}$, Peter Ruggiero ${ }^{4+}$, Julie C.

6 Zinnert $^{2+}$,

7

$8{ }^{1}$ Department of Geological Sciences, University of North Carolina at Chapel Hill, 104 South Rd, 9 Mitchell Hall, Chapel Hill, NC 27599 USA

10 2Department of Biology, Virginia Commonwealth University, Richmond, Virginia 23284, USA

$11{ }^{3}$ Department of Integrative Biology, Oregon State University, 3029 Cordley Hall, Corvallis, 12 Oregon 97331 USA

$13{ }^{4}$ College of Earth, Ocean, and Atmospheric Sciences, Oregon State University, 104 CEOAS

14 Administration Building, 101 SW 26th Street, Corvallis, Oregon 97331 USA 15

$16{ }^{*}$ Corresponding author: evan.goldstein@unc.edu (email); @ebgoldstein (Twitter)

$17{ }^{+}$Denotes equal contribution 
18 Abstract

19

20

21

22

23

24

25

26

27

28

29

30

31

32

33

34

35

36

37

38

39

40

41

42

43

44

45

46

47

48

Previous work on the US Atlantic coast has generally shown that coastal foredunes are dominated by two dune grass species, Ammophila breviligulata (American beachgrass) and Uniola paniculata (sea oats). From Virginia northward, A. breviligulata dominates, while $U$. paniculata is the dominant grass south of Virginia. Previous work suggests that these grasses influence the shape of coastal foredunes in species-specific ways, and that they respond differently to environmental stressors; thus, it is important to know which species dominates a given dune system. The range boundaries of these two species remains unclear given the lack of comprehensive surveys. In an attempt to determine these boundaries, we conducted a literature survey of 98 studies that either stated the range limits and/or included field-based studies/observations of the two grass species. We then produced an interactive map that summarizes the locations of the surveyed papers and books. The literature review suggests that the current southern range limit for A. breviligulata is Cape Fear, NC, and the northern range limit for U. paniculata is Assateague Island, on the Maryland and Virginia border. Our data suggest a northward expansion of $U$. paniculata, possibly associated with warming trends observed near the northern range limit in Painter, VA. In contrast, the data regarding a range shift for $A$. breviligulata remain inconclusive. We also compare our literature-based map with geolocated records from the Global Biodiversity Information Facility and iNaturalist research grade crowd-sourced observations. We intend for our literature-based map to aid coastal researchers who are interested in the dynamics of these two species and the potential for their ranges to shift as a result of climate change.

\section{Introduction}

Coastal foredunes are often the first line of protection against elevated water levels, protecting habitat and infrastructure from flooding and storm impacts (Sallenger, 2000). Coastal dunes are the result of ecomorphodynamic feedbacks - the presence of vegetation leads to localized sand deposition (e.g., Arens, 1996; Kuriyama et al., 2005), and this burial stimulates plant growth (e.g., Maun and Perumal, 1999; Gilbert and Ripley, 2010), resulting in further sand deposition and the eventual development of a vegetated coastal foredune (e.g., Hesp, 1989; Arens, 1996; Arens et al., 2001; Hesp, 2002; McLean and Shen, 2006; Zarnetske et al., 2012; de Vries et al., 2012; Durán and Moore, 2013). 
49

50

51

52

53

54

55

56

57 58

59

60

61

62

63

64

65

66

67

68

69

70

71

72

73

74

75

76

77

78

79

Along the northern portion of the US Atlantic coastline, Ammophila breviligulata Fernald (American beachgrass; perennial $\mathrm{C}_{3}$ plant) is the dominant grass in dune development. In contrast, along the southern coastline, Uniola paniculata L. (sea oats; perennial $\mathrm{C}_{4}$ plant) is the dominant dune-building grass. Other vegetation also contributes to the growth of US east coast dunes and may be locally abundant, including Spartina patens (saltmeadow cordgrass; Lonard et al., 2010), Iva imbricata (dune-marsh elder; Colosi and McCormick, 1978), Schizachyrium littorale (shore little bluestem; Oosting and Billings, 1942; Lonard and Judd, 2010), Carex kobomugi (Asiatic sand sedge; Small et al., 1954; Wootton et al., 2005; Burkitt and Wootton, 2011), and Panicum amarum (bitter panicgrass; Woodhouse et al., 1977; Lonard and Judd, 2011).

Understanding species range limits and their underlying causes has motivated more than a century of research by biogeographers and ecologists (e.g., Grinnell, 1904; Mack, 1996), and is becoming increasingly urgent for environmental management as global environmental change alters species distributions (e.g., Parmesan and Yohe, 2003; Pearson and Dawson, 2003). Descriptions of the range limits of the two dominant dune grasses of the US Atlantic coastline not only improves regional analyses of geomorphology, coastal protection services, and restoration dynamics of east coast dunes, it also provides a baseline for the study of future changes in the range limits of these important dune grasses. Morphological differences in coastal dunes of the US east coast have been attributed to a combination of factors such as forcing conditions (wind, waves, tide), dominant grain size, and vegetative controls such as dune grass species (Godfrey, 1977; Godfrey and Godfrey, 1973; Godfrey et al., 1979). For example, Godfrey (1977) hypothesized that U. paniculata and A. breviligulata differ in their growth rate and growth form, thereby setting the pace of dune growth as well as defining dune shape and size (i.e., hummocky dunes of $U$. paniculata vs. continuous dunes of A. breviligulata), an idea that is consistent with recent model results (Goldstein et al., 2017a). The effects of grass morphology and growth form on dune shape have also been shown on the US west coast, where two nonnative grass species with distinct morphologies and growth characteristics produce differing dune shapes (Hacker et al., 2012; Zarnetske et al., 2012). Broadly, authors have stated that the northern range limit of $U$. paniculata is in Virginia (VA), and the southern limit for $A$. breviligulata is in North Carolina (NC), with species co-occurring in each of the states (e.g., Duncan and Duncan, 1987; Silberhorn, 1999). 
80

81

82

83

84

85

86

87

88

89

90

91

92

93

94

95

96

97

98

99

100

101

102

103

104

105

106

107

108

109

110

Our overall objective in this study is to provide a review and synthesis of previous work on the range limit and locations of $U$. paniculata and A. breviligulata along the US Mid-Atlantic coast as a baseline for future investigations of possible range shifts. To achieve this, we conducted a literature search of papers that contain range limits and occurrences of one or both of the two species at or beyond the generally accepted geographic limits. Our specific goals were to 1 ) determine the range boundaries through time of $U$. paniculata and A. breviligulata from an extensive literature survey and assess the zone of overlap between the two species; 2)

investigate, through temperature trends, whether climate may be playing a role in the boundaries and potential range shifts, and 3) provide a map-based literature review (Tobias, 2014; Tobias and Mandel, 2015) to aid researchers studying the dynamics of the two grass species across their ranges and within their zone of overlap.

\section{Materials \& Methods}

We performed a literature search on December $19^{\text {th }}, 2017$ for published studies in botany, ecology, and coastal geomorphology that specifically include four types of information, which we then collated: 1) statements regarding the northern range limit of U. paniculata; 2) statements regarding the southern range limit of A. breviligulata; 3) studies focusing on these species and their occurrences (in a coastal dune context) at the limits of the stated range, with an emphasis on examples of $A$. breviligulata in NC and southward and U. paniculata in VA and northward; 4) greenhouse and laboratory studies focusing on U. paniculata and A. breviligulata that may relate to their ranges (Supplemental S1). All co-authors participated in the search.

All relevant range data were noted in a spreadsheet shared among the co-authors along with the following information: the author designated place name (e.g., 'Cape Hatteras'), the year published, citation information (e.g., book title, journal, DOI), species ('A' or 'U'), if the stated species was part of an explicit planting experiment, and where in the text the comment on occurrence was made (e.g., 'third column, second paragraph, page three'). Lastly, latitude and longitude were included; either those given in the text, or if not explicitly given, as estimated based on place names provided in the text.

We placed all papers that referenced $U$. paniculata and $A$. breviligulata from $\mathrm{NC}$ to NJ in a shared folder. We used a version of 'snowball' sampling to find new publications by conducting forward and backward searches of our initial set of papers ('cited by' and 'citing') in 
111 Web of Science and Google Scholar to discover new documents. We also searched for previous 112 taxonomic names of U. paniculata - Briza caroliniana J. Lamark, Nevroctola paniculata C.

113 Rafinesque-Schmaltz. ex Jackson, Trisiola paniculata C. Rafinesque-Schmaltz, Nevroctola

114 maritima C. Rafinesque-Schmaltz ex Jackson, Uniola floridana M. Gandoger, Uniola

115 heterochroa M. Gandoger, Uniola macrostachys M. Gandoger; sea oats (Yates, 1966, Lonard et 116 al., 2011) - and A. breviligulata - Ammophila arenaria var. breviligulata (Fernald), though $A$.

117 breviligulata has been a stable species name since the 1920s (Maun and Baye, 1989). Data

118 collection was performed as a 'sprint' during which time authors worked contemporaneously to 119 assemble a database (Goldstein et al., 2017b). We then used the 'Leaflet' Javascript library

120 (Agafonkin, 2017) via an R package (Cheng et al., 2017) in R version 3.4.1 (R Core Team, 2017) 121 to create an interactive map from the collected data (Mullins, 2018).

122 In addition to literature searches, we used the GBIF (The Global Biodiversity Information 123 Facility; GBIF, 2017a) database to extract occurrence records of U. paniculata (GBIF, 2017b; 124 2018b) and A. breviligulata (GBIF, 2018a) on the US east coast, including data from digitized 125 herbarium specimens and research-grade iNaturalist observations (iNaturalist.org. 2018). The $U$. 126 paniculata occurences from GBIF contains data from queries for "U. paniculata L." (GBIF, 127 2018b) and "U. paniculata Roth." (GBIF 2017b). Only GBIF records with latitude and longitude 128 were used. This information was used as a comparison for our interactive map-based literature 129 review.

Finally we used long-term climate data from a NOAA meteorological station in Painter, 131 VA, to examine annual and seasonal trends in temperature between 1956-2016 (Station ID: GHCND:USC00446475). This station is located near the northern range limit of U. paniculata. Data from 2003 is excluded due to missing observations for the month of July. Data are presented as annual mean maximum and minimum temperature and winter (Dec 21 - March 20) mean temperature.

136

\section{Results}

In total, we found 98 unique papers/books/chapters (Table 1) that provided 103 and 158 mentions (specific to the statements in which we searched) of A. breviligulata and U. paniculata, respectively, from 1900 to 2017 (261 total mentions; Figure 1; Supplemental S2). Of the 261 total mentions in our dataset, 32 refer to range boundaries specific enough to place on a map. Of 
142 these 32 mentions spanning 1946 to 2013, 14 are mentions of $U$. paniculata and 18 mentions for 143 A. breviligulata (Table 2; Goldstein et al., 2017b). Because each mention of a range limit is tied 144 to a citation, we were able to collect temporal information on the northern range limit of $U$.

145 paniculata and the southern range limit of $A$. breviligulata (Figure 2). Many mentions of range 146 limits give general geographic information, for instance limiting $U$. paniculata to the 'Virginia 147 Capes', or A. breviligulata to the 'Outer Banks' — this geospatial imprecision prohibits a 148 thorough regression analysis. However, the data in Figure 2 is at least qualitatively suggestive of 149 a slight northward trend in the stated northern range limit of U. paniculata. The data do not allow 150 us to draw conclusions about temporal range shifts for A. breviligulata.

151 We compiled literature mentions of each species in geographic space by placing them on 152 an interactive map (Figure 3; Supplemental S3). The full interactive html map enables users to 153 examine specific observations in greater detail by changing the map scale, selecting individual 154 observations of interest, and navigating to linked primary literature via DOIs or stable URLs. 155 The most southerly studies of A. breviligulata in our dataset are Bright et al. (2011) at Kure 156 Beach, NC and Hosier and Eaton (1980) at Bald Head Beach, NC. The scarcity of references to 157 A. breviligulata in southern NC stands in contrast to the many references of $A$. breviligulata 158 farther north in NC (e.g., Bogue Banks and Cape Lookout). Our literature review suggests that $A$. 159 breviligulata becomes sparse south of Cape Lookout, NC, with no mentions in the literature of 160 its presence south of Cape Fear, NC.

161 North of the Chesapeake Bay mouth, U. paniculata has been observed along the 162 uninhabited islands of the VA eastern shore (Zinnert et al., 2011; Boulé, 1976; Stalter and 163 Lamont, 2000; Bachmann et al., 2002; McCaffrey and Dueser, 1990; Mullins and Moore, 2017). 164 Farther north, U. paniculata appears along Assateague Island (Stalter and Lamont 1990; Hill, 165 1986; Subudhi et al., 2005). We can find reports of only a single stand of $U$. paniculata north of 166 Assateague Island: in Avalon NJ, U. paniculata was planted by the US Department of Agriculture as a trial (Nordstrom, 2008). This experimental stand still exists, but reports in 2013 suggest that no natural recruitment has occurred (USDA, 2013). Our literature review therefore suggests that $U$. paniculata becomes sparse north of the Chesapeake Bay mouth, with only a single (human-planted) stand described north of Assateague Island, MD/VA. indicate a general warming trend in annual maximum $\left(1.0{ }^{\circ} \mathrm{C}, \mathrm{r}^{2}=0.24, \mathrm{p}<0.0001\right)$ and 
173 minimum temperature $\left(2.0{ }^{\circ} \mathrm{C}, \mathrm{r}^{2}=0.52, \mathrm{p}<0.0001\right)$, as well as winter minimum temperature

$174\left(3.6^{\circ} \mathrm{C}, \mathrm{r}^{2}=0.33, \mathrm{p}<0.0001\right)$ since 1956 (Figure 4$)$.

175

176

\section{Discussion}

177

178

179

180

181

182

183

184

185

186

187

188

189

190

191

192

193

194

195

196

197

198

199

200

201

202

203

Thermal tolerances are often implicated in limiting the range of the two species of dune grasses (Ammophila breviligulata and Uniola paniculata) considered in this study. Godfrey (1977) and Lonard et al. (2011) suggest wintertime temperatures limit U. paniculata growth in more northern settings. Seneca $(1969,1972)$ noted that germination below $29^{\circ} \mathrm{C}$ was rare for $U$. paniculata and growth was significantly reduced at low temperatures. Westra and Loomis (1966) and Burgess et al. (2002) also report low rates of $U$. paniculata germination with temperatures below $30^{\circ} \mathrm{C}$. Temperature analysis from Painter, VA (Figure 4) — in the zone of overlap indicates a winter warming trend, potentially resulting in temperatures at or near a threshold limit for successful germination and vegetative propagation of $U$. paniculata (Westra and Loomis, 1966; Seneca 1969,1972; Burgess et al., 2002). Although there are few observations of U. paniculata along the Virginia barrier islands, populations planted experimentally in 2013 have thrived (de Vries et al., in review). Experimentally planted U. paniculata in the higher latitudes of NJ show no natural recruitment (USDA, 2013).

We found no indication of temporal trends in the stated range limit for A. breviligulata in the literature. However, early studies indicate a scarcity of A. breviligulata in southern NC before a history of extensive plantings. Lewis (1918) remarks on the lack of availability of $A$. breviligulata in Beaufort, NC for planting 'barrier dunes' — suggesting instead the use of $U$. paniculata. Ammophila breviligulata is also missing from a Bogue Banks survey by Burk (1962). In contrast to Lewis (1918), van der Valk (1975) notes that the NC Outer Banks were planted with $A$. breviligulata instead of $U$. paniculata during campaigns in the 1930s and 1950s. Schroeder et al. (1976) and Godfrey (1977) also mention plantings of $A$. breviligulata along the NC coastline and Outer Banks. Godfrey (1977), Travis (1977), as well as Maun and Baye (1989) note that $A$. breviligulata plantings occur beyond the probable 'natural' range (i.e., too far south). Seneca and Cooper (1971) find reductions in A. breviligulata biomass as temperatures exceed $26^{\circ} \mathrm{C}$. In addition to thermal constraints, Woodhouse (1977) and Singer (1973) discuss pest and disease pressure in southern populations of A. breviligulata, as does Seliskar and Huettel (1993) for mid-Atlantic A. breviligulata populations. 
204

205

206

207

208

209

210

211

212

213

214

215

216

217

218

219

220

221

222

223

224

225

226

227

228

229

230

231

232

233

234

Several studies that are not included in the map (because they describe greenhouse experiments) are relevant to understanding shifting range limits of these species and interactions that contribute to present-day range limits. These recent experiments focused on species interactions between A. breviligulata and U. paniculata (Harris et al., 2017; Brown et al., 2017), which are likely to be most important in their zone of overlap from NC to VA. Harris et al. (2017) found that $U$. paniculata reduces growth of $A$. breviligulata by altering physiological performance at temperatures consistent with summertime on the Virginia barrier islands. Brown et al. (2017) expanded these results by showing that leaf elongation and root length of $A$.

breviligulata are reduced through interactions with $U$. paniculata. This reduction in performance may explain the observations of $A$. breviligulata plantings being displaced within 6-10 years by native $U$. paniculata along Core Banks, NC (Woodhouse et al., 1968).

The dominant dune grass species in a given area influences the protective services of coastal dunes. Woodhouse et al. (1977) notes that A. breviligulata tends to grow faster than $U$. paniculata and spread more rapidly after transplant growth. These differences in plant growth rate have implications for dune morphology, which have been observed in the field (Woodhouse et al., 1977) and explored in numerical models of coastal dune growth (Goldstein et al., 2017a). These studies suggest that dunes dominated by $A$. breviligulata coalesce faster than those formed by $U$. paniculata, resulting in high, continuous dune ridges compared to hummocky dune formations associated with $U$. paniculata. Further exploration of species interactions in the zone of overlap is needed to fully understand the implications of potential changes in species composition for dune building under future climate change.

Although the focus of our study is on cataloging and mapping data from the literature, absences of $A$. breviligulata or $U$. paniculata in particular areas are also worth noting. For example, we found no reference to A. breviligulata south of Cape Fear, NC. However, there are suggestions in the literature that $A$. breviligulata has been planted further south. Woodhouse and Hanes (1967) advise that $A$. breviligulata can survive when planted for dune restoration purposes as far south as the South Carolina border with North Carolina. Maun and Baye (1989) discuss the presence of planted, ephemeral populations in South Carolina, Georgia, and Florida, but only cite personal communications (with E.D. Seneca) and provide no specific locations. However, comprehensive studies by Stalter $(1974 ; 1975)$ did not mention the occurrence of $A$. breviligulata at several sites in coastal SC. Paired surveys by Stallins $(2002 ; 2005)$ and Stallins and Parker 
235 (2003) also do not record the presence of A. breviligulata in Georgia locations (as compared to 236 NC sites in the same study). This evidence suggests that $A$. breviligulata has, at times, been 237 planted or found south of Cape Fear, NC but fails to persist.

238 We compare our literature-derived results (Figure 3) to the GBIF dataset extracted for 239 this study (GBIF 2017a; 2017b; 2018a; 2018b). Mapping GBIF data associated with known 240 latitude and longitude (636 points) leads to a zone of overlap from Kitty Hawk, NC

241 (southernmost observation of $A$. breviligulata) to Cape Henry, VA (northernmost observation of 242 U. paniculata; Figure 5). Our literature-derived results yields a larger zone of overlap (from 243 Cape Fear, NC to southern NJ), and records many observations from within the zone of overlap 244 (Figure 3).

245

246 Conclusion:

247 Our literature review suggest the current southern range limit for A. breviligulata is Cape 248 Fear, NC, and the northern range limit for U. paniculata is Assateague Island, at the border of 249 Maryland and Virginia. The ranges for these two species overlap between Virginia and North 250 Carolina. Results suggest a northward expansion of U. paniculata, possibly associated with 251 warming trends, while the data for $A$. breviligulata remain inconclusive.

252 We acknowledge that there may be additional information on the ranges of these two 253 dune grass species in theses and local guides (e.g., Denslow et al., 2010). These sources - as 254 well as scanned herbarium sheets from museum collections - constitute 'dark data', data not 255 discoverable because of problems in indexing, storage, and retrieval (Heidorn, 2008). For this 256 reason, a more complete picture of range limits and species abundances should come from 257 contemporaneous, modern, synoptic field surveys of U. paniculata and A. breviligulata 258 throughout the zone of overlap - from NC to NJ. Given the interest in dunes as a means for 259 providing storm protection, it would also be useful to explore the geographic variation of the 260 vigor and survival of natural versus planted stands of these two grasses, including the effects of 261 species interactions. 


\section{Acknowledgements:}

264 We thank Bianca Charbonneau, Louise Wootton, Michele Tobias and the Editor for reviews that 265 improved the manuscript. Map data copyrighted OpenStreetMap contributors and available from 266 https://www.openstreetmap.org.

267

268

269

270

271

272

273

274

275

276

277

278

279

280

281

282

283

284

285

286

287

288

289

290

291

292

293

294

295

296

297

298

299

300

301

302

303

304

305

\section{References:}

Agafonkin V. 2017. Leaflet: an open-source javascript library for mobile-friendly interactive maps. http://leafletjs.com/

Andrews B, Gares PA, Colby JD. 2002. Techniques for GIS modeling of coastal dunes. Geomorphology, 48(1-3), 289-308.

Arens SM. 1996. Patterns of sand transport on vegetated foredunes, Geomorphology, 17, 339350, https://doi.org/10.1016/0169- 555X(96)00016-5

Arens SM, Baas ACW, Van Boxel JH, Kalkman C. 2001. Influence of reed stem density on foredune development. Earth Surface Processes and Landforms, 26(11), 1161-1176.

Bachmann CM, Donato TF, Lamela GM, Rhea WJ, Bettenhausen MH, Fusina RA, Du Bois K, Porter JH, Truitt BR. 2002. Automatic classification of land-cover on Smith Island, VA using HyMAP imagery, IEEE Transactions on Geoscience and Remote Sensing 40: 2313-2330. DOI:10.1109/TGRS.2002.804834

Boulé ME. 1979. The vegetation of Fisherman Island, Virginia. Castanea, 44, 98-108.

Boyce SG. 1954. The salt spray community. Ecological monographs, 24(1), 29-67.

Brantley ST, Bissett SN, Young DR, Wolner CWV, Moore LJ. 2014. Barrier island morphology and sediment characteristics affect the recovery of dune building grasses following storminduced overwash. PLoS One 9(8): e104747. DOI:10.1371/journal.pone.0104747

Bright TM, Burchell MR, Hunt WF, Price W. 2011. Feasibility of a dune infiltration system to protect North Carolina beaches from fecal bacteria contaminated storm water. Journal of Environmental Engineering, 137(10), 968-979.

Brown CA. 1959. Vegetation of the outer banks of North Carolina. Coastal Studies, Series No. 4. Louisiana State Univ. Press., Baton Rouge, La. 179 pp

Brown JK, Zinnert JC, Young DR. 2017. Emergent interactions influence functional traits and success of dune building ecosystem engineers. Journal of Plant Ecology, rtx033, https://doi.org/10.1093/jpe/rtx033 
306 Burgess TL, Blazich FA, Nash DL. 2002. Seed germination of southern seaoats (Uniola 307 paniculata) as influenced by stratification, temperature, and light. Journal of Environmental 308 Horticulture, 20(3), 180-183.

309

310

Burgess TL, Blazich FA, Nash DL, Randall-Schadel B. 2005. Influence of selected surface disinfectants, fungicides, and temperature on seed germination and initial growth of southern seaoats (Uniola paniculata). Journal of Environmental Horticulture, 23(1), 4-8.

312

313

314

315

316

Burk CJ. 1961. A botanical reconnaissance of Portsmouth Island, North Carolina. Journal of the Elisha Mitchell Scientific Society 78, 72-74.

318

319

320

321

Burk CJ. 1962. The North Carolina Outer Banks: a floristic interpretation. Journal of the Elisha Mitchell Scientific Society 78, 21-28.

Burk CJ. 1968. A floristic comparison of lower Cape Cod, Massachusetts and the North Carolina Outer Banks. Rhodora 70, 215-227.

322

323

324

325

326

327

328

329

330

331

332

333

334

335

336

337

338

339

Burkitt J, Wootton L. 2010. Effects of disturbance and age of invasion on the impact of the invasive sand sedge, Carex kobomugi, on native dune plant populations in New Jersey's coastal dunes. Journal of Coastal Research, 27(1), 182-193.

Cheng J, Karambelkar B, Xie Y. 2017. leaflet: Create Interactive Web Maps with the JavaScript 'Leaflet' Library. R package version 1.1.0. https://CRAN.R-project.org/package=leaflet

Cleary WJ, Hosier PE. 1979. Geomorphology, washover history, and inlet zonation: Cape Lookout, NC to Bird Island, NC. In Leatherman SP, ed. Barrier islands-from the Gulf of St. Lawrence to the Gulf of Mexico. New York: Academic Press, 237-271

Colosi JC, McCormick JF. 1978. Population structure of Iva imbricata in five coastal dune habitats. Bulletin of the Torrey Botanical Club, 105: 175-186.

Conaway CA, Wells JT. 2005. Aeolian dynamics along scraped shorelines, Bogue Banks, North Carolina. Journal of Coastal Research 21, 242-254. DOI: 10.2112/01-089.1

Conn CE, Day FP. 1993. Belowground biomass patterns on a coastal barrier island in Virginia. Bulletin of the Torrey Botanical Club 120, 121-127. DOI:10.2307/2996941

Day FP, Conn C, Crawford E, Stevenson M. 2004. Long-term effects of nitrogen fertilization on plant community structure on a coastal barrier island dune chronosequence. Journal of Coastal Ecology 20, 722-730. DOI:10.2112/1551-5036(2004)20[722:LEONFO]2.0.CO;2 transport on decadal timescales. Coastal Engineering, 67, 41-53. 
352

353

354

355

356

357

358

359

360

361

362

363

364

365

366

367

368

369

370

371

372

373

374

375

376

377

378

379

380

381

382

383

384

385

386

387

388

389

390

391

392

393

394

395

396

397
Denslow MW, Palmer MW, Murrell ZE. 2010. A bibliography of North Carolina local floras. Castanea, 75(4), 475-483. DOI: 10.2179/10-015.1

Dilustro JJ, Day FP. 1997. Aboveground biomass and net primary production along a Virginia barrier island dune chronosequence. American Midland Naturalist 137: 27-38.

DOI:10.2307/2426752

Duncan WH, Duncan MB. 1987. The Smithsonian guide to seaside plants of the Gulf and Atlantic Coasts from Louisiana to Massachusetts. Washington, DC: Smithsonian Institution Press. 400 pp.

Durán O, Moore LJ. 2013. Vegetation controls on the maximum size of coastal dunes, P. Natl. Acad. Sci., 110, 17217-17222, https://doi.org/10.1073/pnas.1307580110.

Franks S, Richards CL, Gonzales E, Cousins JE, Hamrick J. 2004. Multi-scale genetic analysis of Uniola paniculata (Poaceae): A coastal species with a linear, fragmented distribution. American Journal of Botany 91:1345-1351. DOI: 10.3732/ajb.91.9.1345

Frankenberg D. 2012. The Nature of North Carolina's Southern Coast: Barrier Islands, Coastal Waters, and Wetlands. Chapel Hill: University of North Carolina Press.

GBIF. 2017a. GBIF: The Global Biodiversity Information Facility. What is GBIF? Available from http://www.gbif.org/what-is-gbif 3rd November 2016.

GBIF. 2017b (20th December 2017) GBIF Occurrence Download https://doi.org/10.15468/dl.bwv8uv

GBIF. 2018a (5th January 2018) GBIF Occurrence Download https://doi.org/10.15468/dl.tb0kxt GBIF. 2018b (6th January 2018) GBIF Occurrence Download https://doi.org/10.15468/dl.hhdbys Gilbert ME, Ripley BS. 2010. Resolving the differences in plant burial responses. Austral Ecology, 35(1), 53-59.

Godfrey, P. J. (1977). Climate, plant response and development of dunes on barrier beaches along the US East Coast. International Journal of Biometeorology, 21(3), 203-216.

Godfrey PJ, Godfrey MM. 1973. Comparison of ecological and geomorphic interactions between altered and unaltered barrier island systems in North Carolina. In Coastal Geomorphology, Coates DR, ed. 239-257, New York: SUNY-Binghamton.

Godfrey PJ, Godfrey MM. 1974. An ecological approach to dune management in the National Recreation Areas of the United States East Coast. International Journal of Biometeorology, 18(2), 101-110. 
398 Godfrey PJ, Godfrey MM. 1976. Barrier island ecology of Cape Lookout National Seashore and 399 vicinity, North Carolina.

400

401

402

403

404

405

406

407

408

409

410

411

412

413

414

415

416

417

418

419

420

421

422

423

424

425

426

427

428

429

430

431

432

433

434

435

436

437

438

439

440

441

442

443

Godfrey PJ, Leatherman SP, Zaremba R. 1979. A geobotanical approach to classification of barrier beach systems. In Letherman SP, ed. Barrier islands-from the Gulf of St. Lawrence to the Gulf of Mexico. New York: Academic Press. 99-126.

Goldstein EB, Moore LJ, Vinent OD. 2017a. Lateral vegetation growth rates exert control on coastal foredune hummockiness and coalescing time. Earth Surface Dynamics, 5(3), 41

Goldstein EB, Mullins E, Moore LJ, Biel RG, Brown JK, Hacker SD, Jay KR, Mostow RS, Ruggiero P, Zinnert JC. 2017b. Locations of published studies focused on Uniola paniculata and Ammophila breviligulata along the US east coast (NJ-NC). Environmental Data Initiative. http://dx.doi.org/10.6073/pasta/bdbe9a609e0508fdb7e39bc41f75bf6f. Dataset accessed 4/24/2018.

Grinnell J. 1904. The origin and distribution of the chestnut-backed chickadee. Auk 21, 364-65.

Hacker SD, Zarnetske P, Seabloom E, Ruggiero P, Mull J, Gerrity S, Jones, C. 2012. Subtle differences in two non-native congeneric beach grasses significantly affect their colonization, spread, and impact, Oikos, 121, 138-148, https://doi.org/10.1111/j.1600-0706.2011.18887.x

Harper JR, Seneca ED. 1974. A preliminary study of flowering in Uniola paniculata along the North Carolina coast. Bulletin of the Torrey Botanical Club 101, 7-13.

Harris AL, Zinnert JC, Young DR. 2017. Differential response of barrier island dune grasses to species interactions and burial. Plant Ecology, 218, 609-619.

Harvill Jr. AM. 1967. The vegetation of Assateague Island, Virginia. Castanea 32: 105-108

Heidorn PB. 2008. Shedding light on the dark data in the long tail of science. Library Trends, 57(2), 280-299.

Hesp PA. 1989. A review of biological and geomorphological processes involved in the initiation and development of incipient foredunes, in: Coastal Sand Dunes, edited by:

Gimingham, CH, Ritchie, W, Willetts, BB, and Willis, AJ, Proceedings of Royal Society, Edinburgh, 96B, 181-201.

Hesp PA. 2002. Foredunes and blowouts: initiation, geomorphology and dynamics, Geomorphology, 48, 245-268, https://doi.org/10.1016/S0169-555X(02)00184-8.

Heyel SM, Day FP. 2006. Long-term residual effects of nitrogen addition on a barrier island dune ecosystem. The Journal of the Torrey Botanical Society 133, 297-303.

Hill SR. 1986. An annotated checklist of the vascular flora of Assateague Island (Maryland and Virginia). Castanea 51, 265-305 
444

445

446

447

448

449

450

451

452

453

454

455

456

457

458

459

460

461

462

463

464

465

466

467

468

469

470

471

472

473

474

475

476

477

478

479

480

481

482

483

484

485

486

487

488

489

Hitchcock AS. 1935. Manual of the Grasses of the United States, by AS Hitchcock,.. (No. 584.90973 H58.). US Government Printing Office.

Hitchcock AS, Chase A. I950 Manual of the grasses of the United States. US Dep. Agric. Misc. Publ, 200, 1051.

Hodel RG, Gonzales E. 2013. Phylogeography of Sea Oats (Uniola paniculata), a dune-building coastal grass in southeastern North America. Journal of Heredity 104, 656-665.

DOI:10.1093/jhered/est035

Hosier PE, Cleary WJ. 1977. Cyclic geomorphic patterns of washover on a barrier island in southeastern North Carolina. Environmental Geology 2, 23. DOI:10.1007/BF02430662

Hosier PE, Eaton TE. 1980. The impact of vehicles on dune and grassland vegetation on a southeastern North Carolina barrier beach. Journal of Applied Ecology, 17: 173-182.

iNaturalist.org. 2018. iNaturalist Research-grade Observations. Occurrence Dataset

https://doi.org/10.15468/ab3s5x accessed via GBIF.org on 2018-04-06.

Kearney TH. 1900. The plant covering of Ocracoke Island: A study in the ecology of the North Carolina strand vegetation. Contributions to the U.S. National Herbarium 5, 261-319.

Kearney TH 1901. Report on a botanical survey of the Dismal Swamp region. Contributions to the U.S. National Herbarium 6, 321-552.

Klotz L. 1986. The vascular flora of Wallops Island and Wallops Mainland, Virginia. Castanea, 51(4), 306-326.

Koske RE, Polson WR. 1984. Are VA mycorrhizae required for sand dune stabilization?

BioScience 34, 420-424.

Krause JW. 1988. A guide to ocean dune plants common to North Carolina. UNC Press, 72pp.

Kuriyama Y, Mochizuki N, Nakashima T. 2005. Influence of vegetation on aeolian sand transport rate from a backshore to a foredune at Hasaki, Japan, Sedimentology, 52, 1123-1132, https://doi.org/10.1111/j.1365-3091.2005.00734.x

Laing C. 1958. Studies in the ecology of Ammophila breviligulata. I. Seedling survival and its relation to population increase and dispersal. Botanical Gazette 119, 208-216.

Levy GF. 1976. Vegetative study at the Duck Field Research Facility, Duck, North Carolina, Miscellaneous Report No. 76-6 April 1976

Lewis IF. 1918. The vegetation of Shackleford Banks, Carteret County, North Carolina. North Carolina Geological and Economic Survey Economic paper 46 
490

491

492

493

494

495

496

497

498

499

500

501

502

503

504

505

506

507

508

509

510

511

512

513

514

515

516

517

518

519

520

521

522

523

524

525

526

527

528

529

530

531

532

533

534

Lonard RI, Judd FW. 2010. The biological flora of coastal dunes and wetlands: Schizachyrium littorale (G. Nash) E. Bicknell. Journal of Coastal Research, 26, 654-662.

Lonard RI, Judd FW. 2011. The biological flora of coastal dunes and wetlands: Panicum amarum S. Elliott and Panicum amarum S. Elliott var. amarulum (AS Hitchcock and MA Chase) P. Palmer. Journal of Coastal Research, 27(2), 233-242.

Lonard RI, Judd FW, Stalter R. 2010. The biological flora of coastal dunes and wetlands: Spartina patens (W. Aiton) GH Muhlenberg. Journal of Coastal Research, 935-946.

Lonard RI, Judd FW, Stalter R. 2011. Biological flora of coastal dunes and wetlands: Uniola paniculata L. Journal of Coastal Research 27, 984-993.

Long ZT, Fegley SR, Peterson CH. 2013a. Suppressed recovery of plant community composition and biodiversity on dredged fill of a hurricane-induced inlet through a barrier island. Journal of Coastal Conservation 7, 493-501.

Long ZT, Fegley SR, Peterson CH 2013b. Fertilization and plant diversity accelerate primary succession and restoration of dune communities. Plant Ecology 214, 1419-1429.

Mack RN. 1996. Predicting the identity and fate of plant invaders: emergent and emerging approaches. Biological Conservation, 78, 107-121.

Martin WE. 1959. The vegetation of Island Beach State Park, New Jersey. Ecological Monographs, 29(1), 1-46.

Maun MA, Baye PR. 1989. The ecology of Ammophila breviligulata Fern. on coastal dune systems. CRC Critical Reviews in Aquatic Sciences, 1, 661-681.

Maun MA, Perumal J. 1999. Zonation of vegetation on lacustrine coastal dunes: effects of burial by sand. Ecology Letters, 2(1), 14-18.

McCaffrey CA, Dueser RD. 1990. Preliminary vascular flora for the Virginia barrier islands.

Virginia Journal of Science 41, 259-281

McLean R, Shen JS. 2006. From foreshore to foredune: Foredune development over the last 30 years at Moruya Beach, New South Wales, Australia. Journal of Coastal Research, 22: 28-36.

Mullins EV. 2018. elsemar/EastCoastDuneGrass: Map for Lit review (Version 1.1). Zenodo. http://doi.org/10.5281/zenodo.1228461

Mullins EV, Moore LJ. 2017. Locations of Uniola paniculata on selected Virginia Barrier Islands, 2017. Environmental Data Initiative. doi:10.6073/pasta/08d29335a6993474ff19c847e0817f37. Dataset accessed 1/20/2018. 
535 Nordstrom KF. 2008. Beach and dune restoration. Cambridge: Cambridge University Press.

$536 \quad 187 \mathrm{p}$

537

538

539

540

541

542

543

544

545

546

547

548

549

550

551

552

553

554

555

556

557

558

559

560

561

562

563

564

565

566

567

568

569

570

571

572

573

574

575

576

577

578

579

580

Odum WE, Smith TJ, Dolan R. 1987. Suppression of natural disturbance: long-term ecological change on the Outer Banks of North Carolina. In: Turner M.G. (eds) Landscape Heterogeneity and Disturbance. Ecological Studies, vol. 64. Springer, New York, NY.

Oosting HJ. 1945. Tolerance to salt spray of coastal dunes. Ecology 26, 85-89

Oosting H, Billings W. 1942. Factors affecting vegetational zonation on coastal dunes. Ecology 23, 131-142. DOI:10.2307/1931081

Overlease, WR. 1991. Some observations of dune plant communities from Cape Cod, Massachusetts to southern Florida and the Gulf of Mexico along a 2400 kilometer north-south transect. Journal of the Pennsylvania Academy of Science 65, 51-55.

Parmesan C, Yohe G. 2003. A globally coherent fingerprint of climate change impacts across natural systems. Nature 421(6918), 37.

Pearson RG, Dawson TP. 2003. Predicting the impacts of climate change on the distribution of species: are bioclimate envelope models useful?. Global Ecology and Biogeography, 12(5), 361371.

Pilkey OH, Rice TM, Neal WJ. 2004. How to Read a North Carolina Beach: Bubble Holes, Barking Sands, and Rippled Runnels. Chapel Hill: UNC Press Books.

Purvis KG, Gramling JM, Murren CJ. 2015. Assessment of beach access paths on dune vegetation: diversity, abundance, and cover. Journal of Coastal Research, 31(5), 1222-1228.

R Core Team. 2017. R: A language and environment for statistical computing. R Foundation for Statistical Computing, Vienna, Austria. URL https://www.R-project.org/.

Rogers SM, Nash D. 2003. The dune book. North Carolina Sea Grant.

Roman CT, Nordstrom, KE. 1988. The effect of erosion rate on vegetation patterns of an east coast barrier island. Estuarine, Coastal, and Shelf Science 26, 233-242.

Sallenger Jr AH. 2000. Storm impact scale for barrier islands. Journal of Coastal Research, 16: 890-895.

Schroeder PM, Dolan R, Hayden BP. 1976. Vegetation changes associated with barrier-dune construction on the Outer Banks of North Carolina. Environmental Management, 1(2), 105-114.

Schroeder PM, Hayden B, Dolan R. 1979. Vegetation changes along the United States east coast following the great storm of March 1962. Environmental Management 3: 331-338.

DOI:10.1007/BF01867440 
581

582

583

584

585

586

587

588

589

590

591

592

593

594

595

596

597

598

599

600

601

602

603

604

605

606

607

608

609

610

611

612

613

614

615

616

617

618

619

620

621

622

623

624

625

Seliskar DM. 1994. The effect of accelerated sand accretion on growth, carbohydrate reserves, and ethylene production in Ammophila breviligulata (Paoceae). American Journal of Botany 81: 536-541.

Seliskar DM. 1995. Coastal dune restoration: A strategy for alleviating dieout of Ammophila breviligulata. Restoration Ecology 3, 54-60. DOI:10.1111/j.1526-100X.1995.tb00075.x

Seliskar DM. 2003. The response of Ammophila breviligulata and Spartina patens to grazing by feral horses on a dynamic mid-atlantic barrier island. American Journal of Botany 90, 10381044. DOI: 10.3732/ajb.90.7.1038

Seliskar DM and Huettel RN. 1993. Nematode involvement in the dieout of Ammophila breviligulata (Poaceae) on the Mid-Atlantic coastal dunes of the United States. Journal of Coastal Research 9, 97-103

Seneca E. 1969. Germination response to temperature and salinity of four dune grasses from the Outer Banks of North Carolina. Ecology 50, 45-53. DOI:10.2307/1934661

Seneca E. 1972. Germination and seedling response of Atlantic and Gulf Coasts populations of Uniola paniculata. American Journal of Botany 59, 290-296.

Seneca ED, Cooper AW. 1971. Germination and seedling response to temperature, daylength, and salinity by Ammophila breviligulata from Michigan and North Carolina. Botanical Gazette 132, 203-215. DOI: 10.1086/336580

Shafer JK. 2010. Interisland Variability of Dune Plant Community Structure (Doctoral dissertation, Old Dominion University).

Silander JA, Antonovics J. 1982. Analysis of interspecific interactions in a coastal plant community - a perturbation approach. Nature 298, 557-560. DOI:10.1038/298557a0

Silberhorn GM. 1999. Common plants of the Mid-Atlantic Coast: a field guide. Baltimore: The Johns Hopkins University Press.

Singer R, Lucas LT, Warren TB. 1973. The Marasmius-Blight fungus. Mycologia 65, 468-473

Small JA. 1954. Carex kobomugi at Island Beach, New Jersey. Ecology, 35(2), 289-291.

Stallins JA. 2002. Dune plant species diversity and function in two barrier island biogeomorphic systems. Plant Ecology 165, 138-196. DOI: 10.1023/A:10222242

Stallins JA. 2005. Stability domains in barrier island dune systems. Ecological Complexity 2, 410-430. DOI: 10.1016/j.ecocom.2005.04.011 
626 Stallins JA, Parker AJ. 2003. The influence of complex systems interactions on barrier island 627 dune vegetation pattern and process. Annals of the Association of American Geographers 93, 13-

628

629

630

631

632

633

634

635

636

637

638

639

640

641

642

643

644

645

646

647

648

649

650

651

652

653

654

655

656

657

658

659

660

661

662

663

664

665

666

667

668

669

670

671

29. DOI: $10.1111 / 1467-8306.93102$

Stalter R. 1974. Vegetation in coastal dunes of South Carolina. Castanea, 39: 95-103.

Stalter R. 1975. The flora of the Isle of Palms, South Carolina. Castanea, 40: 4-13.

Stalter R, Lamont EE. 1990. The vascular flora of Assateague Island, Virginia. Bulletin of the Torrey Botanical Club 117: 48-56.

Stalter R, Lamont EE. 1997. Flora of North Carolina's Outer Banks, Ocracoke Island to Virginia. Journal of the Torrey Botanical Society 124: 71-88.

Stalter R, Lamont EE. 1999. Vascular flora of Cape Lookout National Seashore and Bogue Banks, North Carolina. Journal of the Elisha Mitchell Scientific Society, 115: 213-235.

Stalter R, and Lamont EE. 2000. Vascular flora of Fisherman Island, Virginia. The Journal of the Torrey Botanical Society, 127, 324-332

Subudhi PK, Parami NP, Harrison SA, Materne MD, Murphy JP, Nash D. 2005. An AFLP-based survey of genetic diversity among accessions of sea oats (Uniola paniculata, Poaceae) from the southeastern Atlantic and Gulf coast states of the United States. Theoretical and Applied

Genetics 111, 1632-1641. DOI: 10.1007/s00122-005-0096-y

Tatnall RR. 1946. Flora of Delaware and the Eastern Shore: An annotated list of the fern and flowering plants on the peninsula of Delaware, Maryland, and Virginia. Lancaster, Pennsylvania: Society of Natural History of Delaware.

Thornhill R, Suiter D, Krings A. 2013. Native plants for coastal North Carolina landscapes. The National Fish and Wildlife Foundation.

Tobias MM, Mandel AI. 2015. Literature Mapper. QGIS Plugin. https://github.com/MicheleTobias/LiteratureMapper

Tobias M. 2014. Map: A Geographic Research Review for California. figshare. https://doi.org/10.6084/m9.figshare.1100493.v3

Travis R. 1977. The effects of aspect and exposure on the growth of dune grasses in Cape Hatteras National Seashore. Int J Biometeor 3, 217-226.

Tyndall RW, Teramura AH, Mulchi CL, Douglass LW. 1986. Seed burial effect on species presence along a mid-Atlantic beach. Canadian Journal of Botany 64, 2168-2170.

Tyndall RW, Teramura AH, Mulchi CL, Douglass LW. 1987. Effects of salt spray upon seedling survival, biomass, and distribution on Currituck Bank, North Carolina. Castanea 52, 77-86. 
672

673 USDA. 2013. Progress Report of Activities 2013, Cape May Plant Materials Center, available at:

674

675

676

677

678

679

680

681

682

683

684

685

686

687

688

689

690

691

692

693

694

695

696

697

698

699

700

701

702

703

704

705

706

707

708

709

710

711

712

713

714

715

716

717

http://www.nrcs.usda.gov/Internet/FSE PLANTMATERIALS/publications/njpmcra12114.pdf

van der Valk AG. 1974. Mineral cycling in coastal foredune plant communities in Cape Hatteras National Seashore. Ecology 55, 1349-1358

van der Valk AG. 1975. The floristic composition and structure of foredune plant communities of Cape Hatteras National Seashore. Chesapeake Science 16, 115-126.

van der Valk, AG. 1977. The role of leaves in the uptake of nutrients by Uniola paniculata and Ammophila breviligulata. Chesapeake Science 18, 77-79.

Wagner R. 1964. The ecology of Uniola paniculata L. in the dune-strand habitat of North Carolina. Ecological Monographs 34, 79-96.

Wells BW. 1928. Plant communities of the coastal plain of North Carolina and their successional relations. Ecology 9, 230-242.

Westra RN, Loomis WE. 1966. Seed dormancy in Uniola paniculata. American Journal of Botany, 407-411.

Wolner CWV, Moore LJ, Young DR, Brantley ST, Bissett SN, McBride RA. 2013.

Ecomorphodynamic feedbacks and barrier island response to disturbance: Insights from the Virginia Barrier Islands, Mid-Atlantic Bight, USA, Geomorphology, 199, 115-128, https://doi.org/10.1016/j.geomorph.2013.03.035.

Woodhouse Jr WW. 1982. Coastal sand dunes of the U.S. In Creation and restoration of coastal plant communities. Edited by R.R. Lewis III. CRC Press Inc., Boca Raton, Fla. pp. 1-44.

Woodhouse Jr WW, Hanes RE. 1967. Dune stabilization with vegetation on the Outer Banks of North Carolina (No. TM-22). Coastal Engineering Research Center, Vicksburg, MS.

Woodhouse WW, Seneca ED, Cooper AW. 1968. Use of sea oats for dune stabilization in the southeast. Shore and Beach 36, 15-21.

Woodhouse WW, Seneca ED, Broome SW. 1977. Effect of species on dune grass growth International. Journal of Biometeorology, 21, 256-266.

Wootton LS, Halsey SD, Bevaart K, McGough A, Ondreicka J, Patel P. 2005. When invasive species have benefits as well as costs: managing Carex kobomugi (Asiatic sand sedge) in New Jersey's coastal dunes. Biological Invasions, 7(6), 1017-1027.

Yates HO. 1966. Revision of grasses traditionally referred to Uniola, I. Uniola and Leptochloöpsis. The Southwestern Naturalist, 11: 372-394. 
718 Young DR, Brantley ST, Zinnert JC, Vick JK. 2011. Landscape position and habitat polygons in 719 a dynamic coastal environment. Ecosphere, 2(6), 1-15.

720

721 Yousefi Lalimi F, Silvestri S, Moore LJ, Marani M. 2017. Coupled topographic and vegetation 722 patterns in coastal dunes: Remote sensing observations and ecomorphodynamic implications. 723 Journal of Geophysical Research: Biogeosciences, 122(1), 119-130.

724

725

726

727

728

729

730

731
Zarnetske PL, Hacker SD, Seabloom EW, Ruggiero P, Killian JR, Maddux TB, Cox D. 2012. Biophysical feedback mediates effects of invasive grasses on coastal dune shape, Ecology, 93, 1439-1450, https://doi.org/10.1890/11-1112.1.

Zinnert JC, Shiflett SA, Vick JK, Young DR. 2011. Woody vegetative cover dynamics in response to recent climate change on an Atlantic Coast barrier island using Landsat TM imagery, Geocarto International, 26, 595-612, https://doi.org/10.1080/10106049.2011.621031. 


\section{Table $\mathbf{1}$ (on next page)}

References used in construction of the interactive map

A total of 82 citations; 22 for Ammophila breviligulata, 30 for Uniola paniculata, and 30 for both species. 


\begin{tabular}{|c|c|}
\hline Species & Citation \\
\hline A. breviligulata & $\begin{array}{l}\text { Martin, 1959; Woodhouse and Hanes, 1967; Seneca and Cooper, 1971; } \\
\text { Singer et al., 1973; Harvil, 1979; Schroeder et al., 1979; Koske and } \\
\text { Polson, 1984; Klotz, 1986; Roman and Nordstrom, 1988; Conn and Day, } \\
\text { 1993; Seliskar and Huettel, 1993; Seliskar, 1994; Seliskar, 1995; Dilustro } \\
\text { and Day, 1997; Seliskar, 2003; Day et al., 2004; Conaway and Wells, } \\
\text { 2005; Heyel and Day, 2006; Young et al., 2011; Wolner et al., 2013; } \\
\text { Brantley et al., 2014; Yousefi Lalimi et al., } 2017\end{array}$ \\
\hline U. paniculata & $\begin{array}{l}\text { Lewis, 1918; Hitchcock, 1935; Wells, 1928; Oosting and Billings, 1942; } \\
\text { Oosting, 1945; Tatnall, 1946; Burk, 1961; Wagner, 1964; Seneca, 1972; } \\
\text { Godfrey and Godfrey, 1974; Harper and Seneca, 1974; Stalter, 1975; } \\
\text { Cleary and Hosier, 1979; Godfrey and Godfrey, 1976; Godfrey, 1979; } \\
\text { Hosier and Cleary, 1977; Silander and Antonovics, 1982; Tyndall et al., } \\
\text { 1986; Tyndall et al., 1987; Stallins, 2002; Franks et al., 2004; Subudhi et } \\
\text { al., 2005; Burgess et al., 2005; Zinnert et al., 2011; Hodel and Gonzales, } \\
\text { 2013; Long et al., 2013a; Long et al., 2013b; USDA, 2013; Purvis et al., } \\
\text { 2015; Mullins and Moore, } 2017\end{array}$ \\
\hline A. breviligulata and U. paniculata & $\begin{array}{l}\text { Kearney, 1900; Kearney, 1901; Boyce, 1954; Brown, 1959; Burk, 1962; } \\
\text { Woodhouse et al., 1968; Seneca, 1969; Godfrey and Godfrey, 1973; van } \\
\text { der Valk, 1974; van der Valk, 1975; Levy, 1976; Travis, 1977; van der } \\
\text { Valk, 1977; Woodhouse et al., 1977; Godfrey, 1977; Boulé, 1979; Hosier } \\
\text { and Eaton, 1980; Hill, 1986; Odum et al., 1987; McCaffrey and Dueser, } \\
\text { 1990; Stalter and Lamont, 1990; Stalter and Lamont, 1997; Stalter and } \\
\text { Lamont, 1999; Stalter and Lamont, 2000; Andrews, 2002; Bachmann et } \\
\text { al., 2002; Shafer, 2003; Stallins and Parker, 2003; Stallins, 2005; Bright et } \\
\text { al., } 2011\end{array}$ \\
\hline
\end{tabular}




\section{Table 2 (on next page)}

References with mentions to range limits

A total of 24 citations; 10 for Ammophila breviligulata, 6 for Uniola paniculata, and 8 for both species. 


\begin{tabular}{|l|l|}
\hline Species & Citation \\
\hline A. breviligulata & $\begin{array}{l}\text { Brown, 1959; Burk, 1968; Godfrey and Godfrey, 1973; Godfrey and } \\
\text { Godfrey, 1976; Godfrey et al., 1979; Maun and Baye, 1989; Rogers and } \\
\text { Nash, 2003; Pilkey et al., 2004; Frankenberg, 2012; Thornhill et al., } 2013\end{array}$ \\
\hline U. paniculata & $\begin{array}{l}\text { Liang, 1958; Wagner, 1964; Yates, 1966; Woodhouse, 1982; Lonard et } \\
\text { al., 2011; Hodel and Gonzales, 2013 }\end{array}$ \\
\hline A. breviligulata and U. paniculata & $\begin{array}{l}\text { Hitchcock and Chase, 1950; Woodhouse and Hanes, 1967; Seneca, 1972; } \\
\text { Godfrey, 1977; Duncan and Duncan, 1987; Krause, 1988; Overlease, 1991; } \\
\text { Silberhorn, 1999; }\end{array}$ \\
\hline
\end{tabular}

1 


\section{Figure 1 (on next page)}

Dataset composition

Dates for all referenced work for each species in our dataset, binned every 5 years. 


\section{Figure 2 (on next page)}

\section{Range Limits}

Southern range limit for $A$. breviligulata (A) and northern range limit U. paniculata (B), extracted from literature sources of various age. Points are specific geographic mentions, while lines are ambiguous geographical references ( e.g., 'Southern North Carolina, 'Virginia Capes'). Dotted lines demarcate state boundaries. 
PeerJ

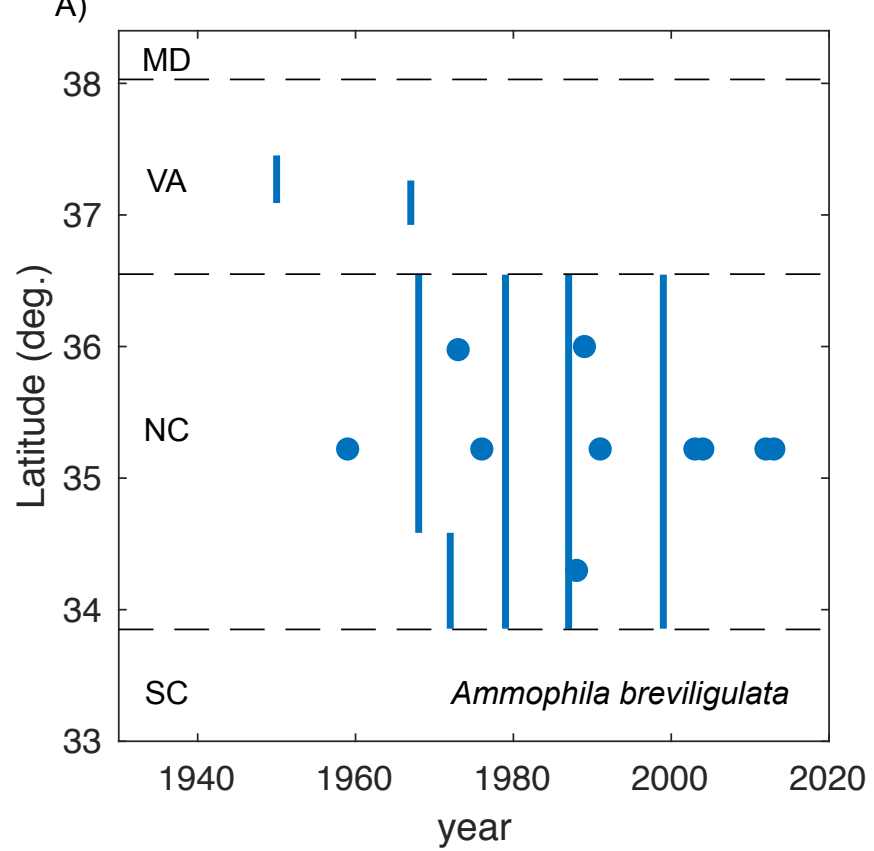

Manuscript to be reviewed

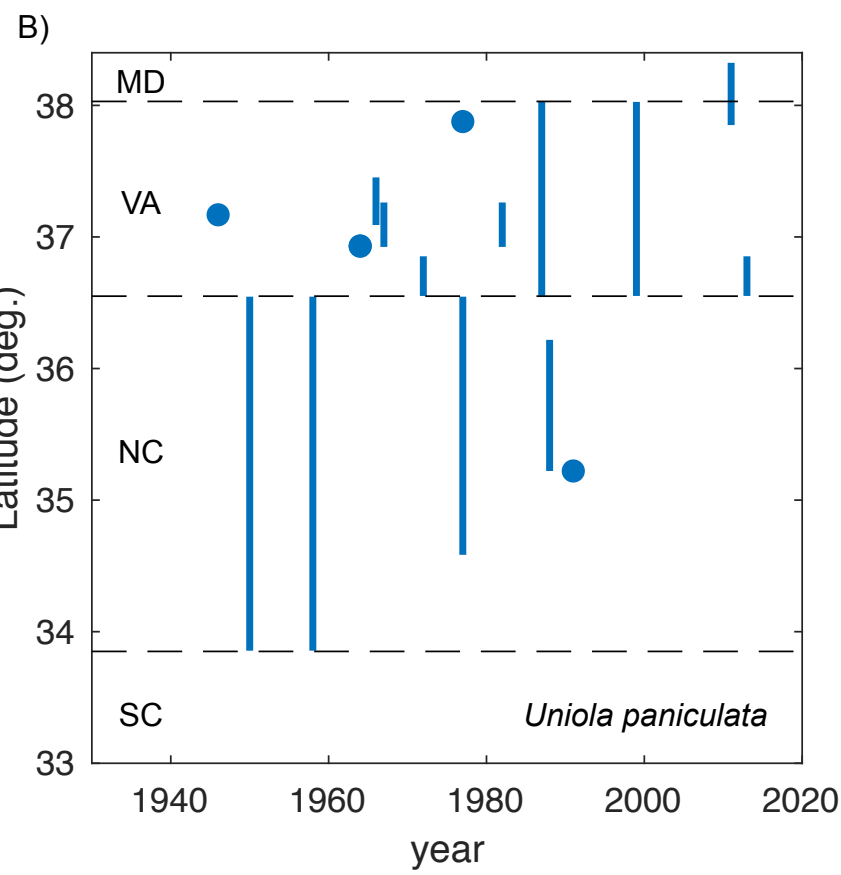




\section{Figure 3}

Static snapshot of interactive map

A static snapshot of the interactive map (Supplemental S3). The map background is OpenStreetMap data (https://www.openstreetmap.org). Each circle marker corresponds to a literature mention of a given species (orange for A. breviligulata, blue for U. paniculata, purple for both). Filled markers are literature defined locations (mentioned in the specific study). Open markers are general locations estimated by place names in the study text. In the interactive map (Supplemental S3), mentions can be seen within the pop-up label, as well as the corresponding species label ('A' or ' $U$ '), a location name ('Bald Head Beach') and an active link via the a DOI or stable URL to primary source. 


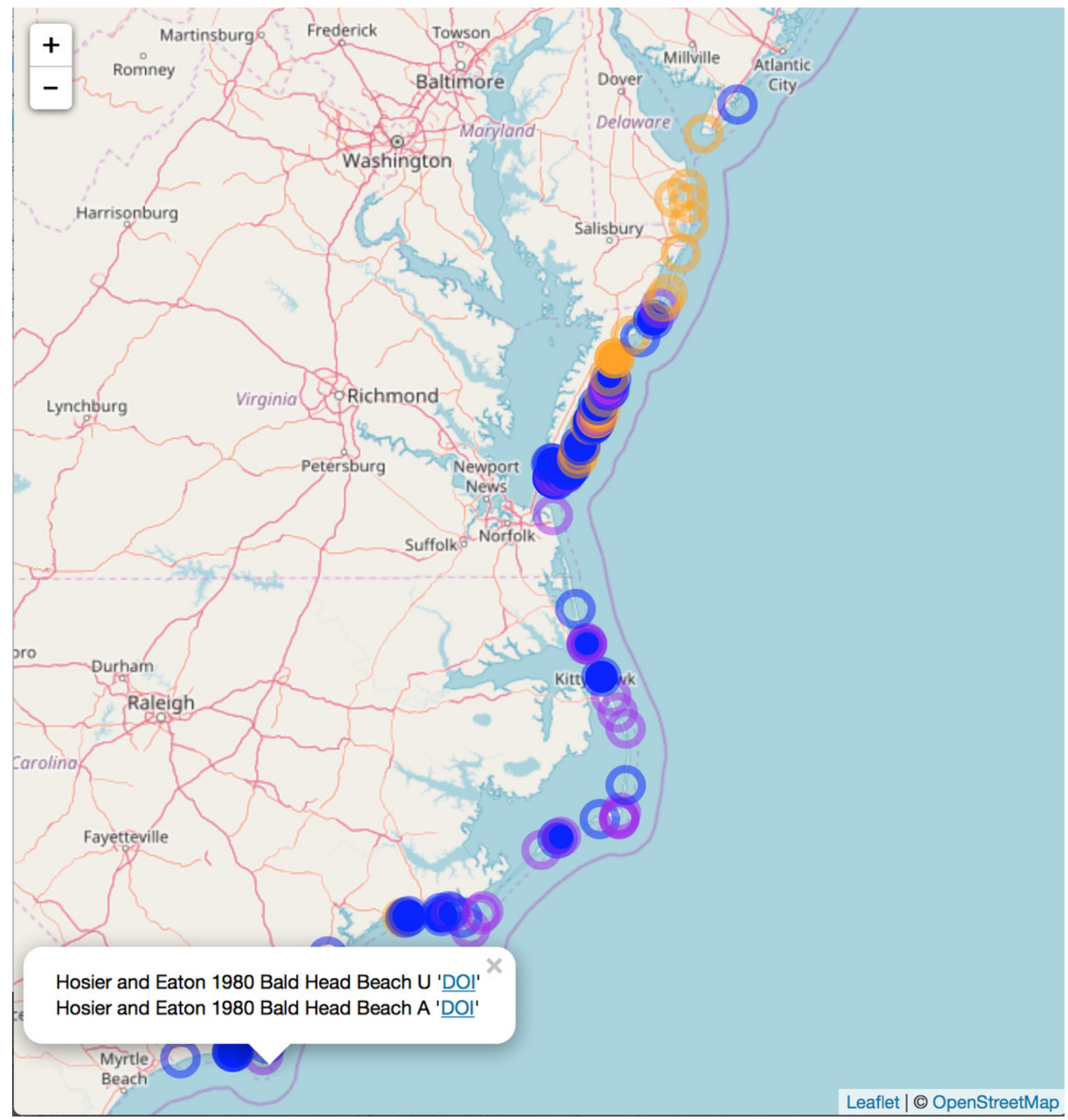




\section{Figure 4}

Painter, VA temperature trends

Observations and trends of increasing annual mean of the maximum temperature $(A)$, annual mean of the minimum temperature (B), and winter (Dec 21 - March 20) mean temperature (C) at Painter, VA, near the northern range limit of U. paniculata. 


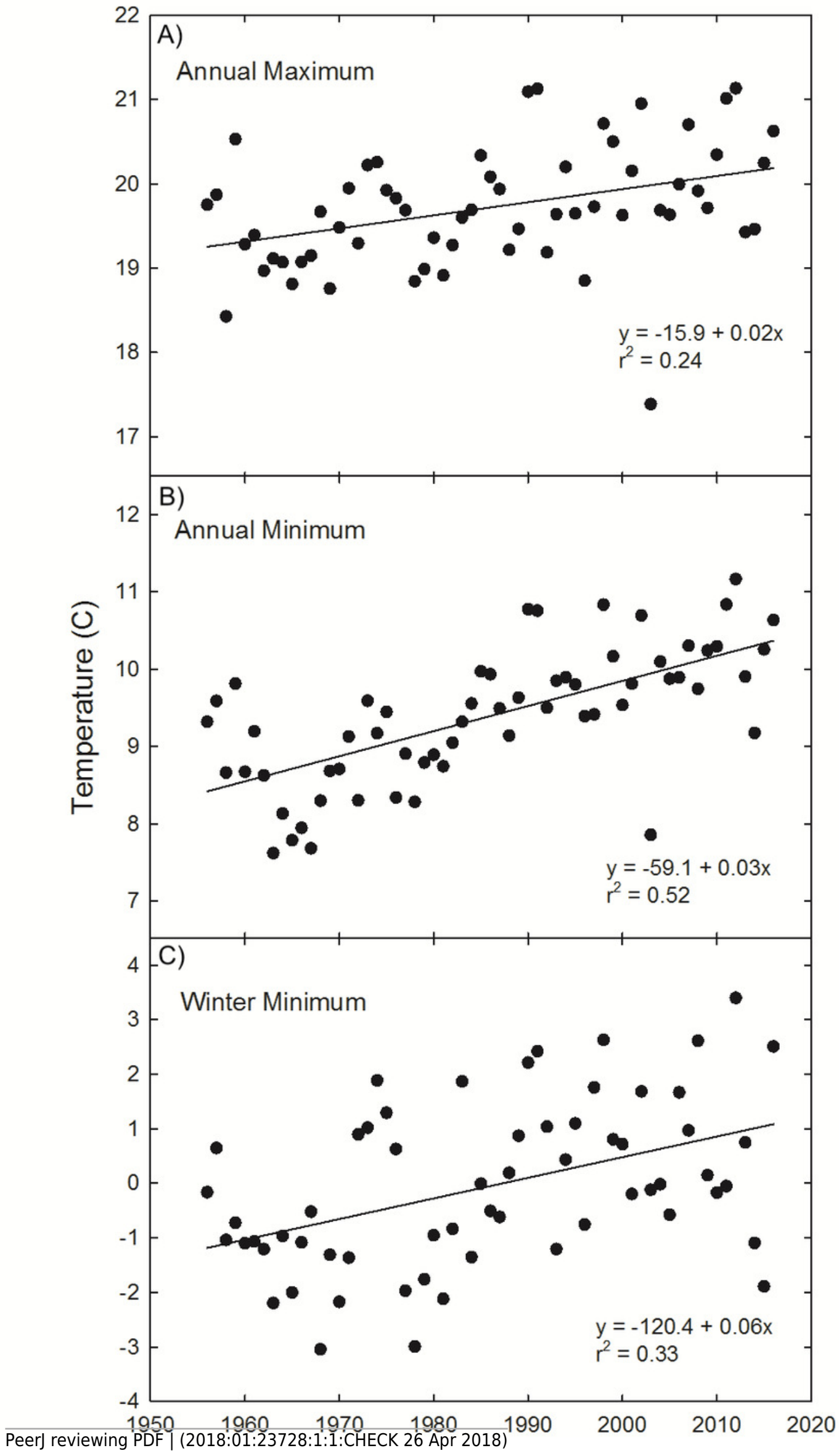


Figure 5

\section{GBIF data}

Map of $A$. breviligulata (orange) and U. paniculata (blue) occurences from the GBIF database.

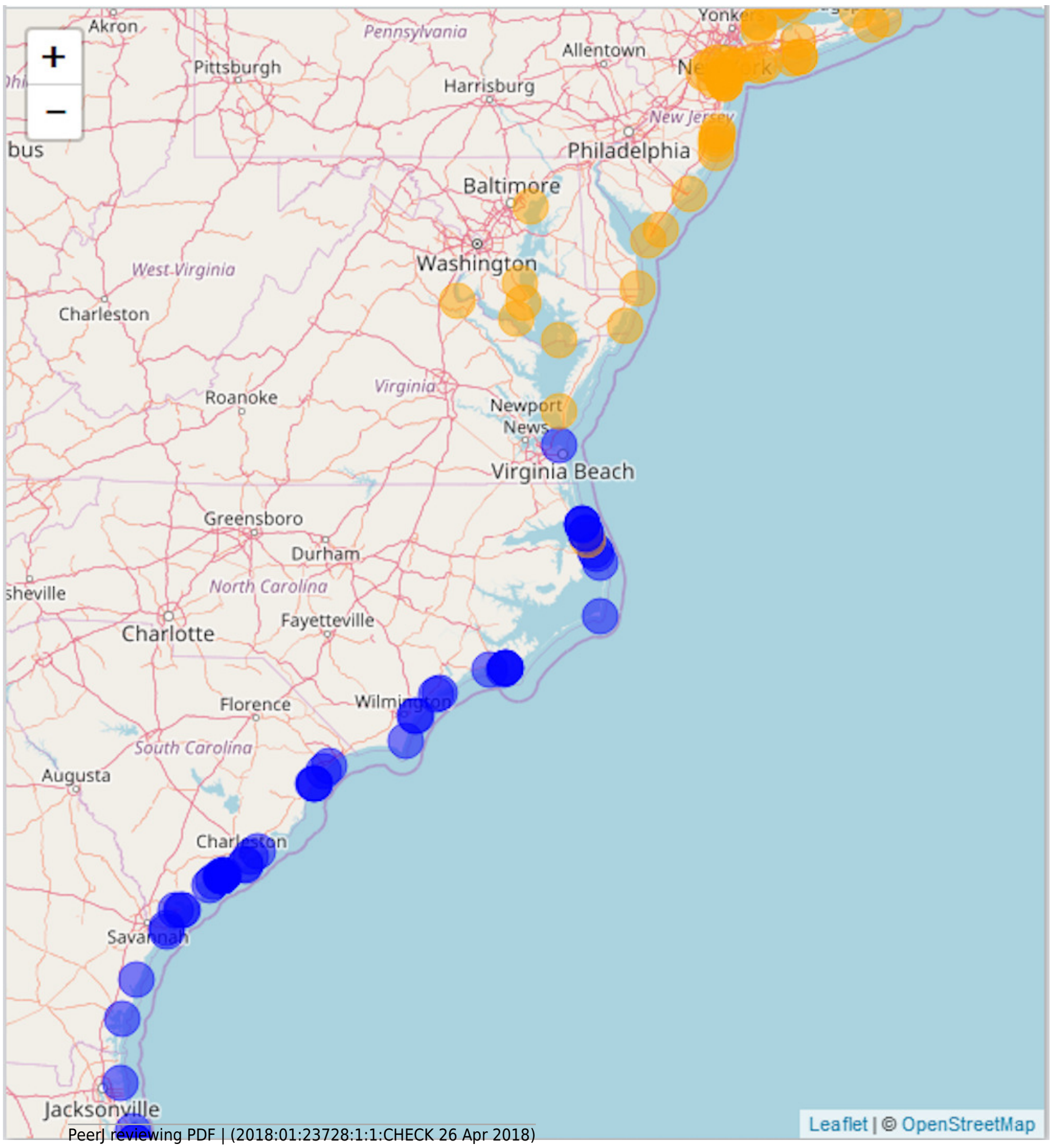

